\title{
The Rise and Fall of a Science of Adult Education at The University of British Columbia, 1957-85
}

\author{
Eric J. Damer
}

In 1957 the University of British Columbia [UBC] launched Canada's first degree programme in adult e ducation. UBC was enjoying a decade of rapid expansion, and its new Faculty of Education provided a new home to teacher training and other educational specialities. Although adult education had been promoted during the 1940s and 1950s with other helping professions, it entered UBC with the help of influential men rather than through student demand or intellectual innovation. The programme was the creation of a close network of administrators: President Norman A. M. MacKenzie, Director of Extension John Friesen, Dean of Education Neville Scarfe, and other administrative heads across campus. These old friends shared a view of social progress through managed social change and public institutions, flavoured with moderate social-gospel sentiments.

Thirty years later, the dependency of adult education was as great as it had been at the outset. The question remained: was the field of adult education sustainable at UBC without a supporting network of friendly administrators? Indeed, was there a theoretically-grounded "field" at UBC? Answers to these questions require a close study of adult education's origins, not just its fin-desiècle condition.

MacKenzie's nephew Allan Thomas organized the adult education programme to explore the social, economic, political, and ethical dimensions of adult education practice. The curriculum changed significantly in 1959 with a visit by American Coolie Verner, a graduate of Columbia University (like Friesen and, later, Thomas). As an Associate Professor at Florida State University since 1953, Verner promoted adult education as applied social science, promising to provide the "fundamental knowledge about educating adults that is common to every situation."

Welcomed into MacKenzie's network in 1961 as Professor of Adult Education, Verner was given administrative free reign to find and to teach this fundamental knowledge. He immediately set about selecting a staff and a curriculum.

Columbia University had introduced Verner to social inquiry as the disinterested and empirical study of value-neutral social "facts" and their static, social

'Coolie Verner, "Organizing Graduate Professional Education for Adult Education" (1969), reprinted in J. Roby Kidd and Gordon Selman, eds., Coming of Age: Canadian Adult Education in the 1960s (Toronto: Canadian Association for Adult Education, 1978), 134.

(c) Historical Studies in Education/Revue d'bistoire de l'éducation 12, nos. 1/2 (2000): 29-53. 
patterns. ${ }^{2}$ In the Chicago-Columbia tradition of the day, the "functionalist" school of sociology saw ideal human societies as stable and harmonious inter-related systems. ${ }^{3}$ Consistent with positivist ideals, sociological research gathered observable and quantifiable evidence to describe, predict, and control external social reality. Research methodology relied on statistical analysis of quantified data gathered in social surveys, analysis in which Verner quickly became proficient.

Verner saw adult education as a field of practice and an academic discipline. His Columbia mentors Wilbur Hallenbeck and Edmund de Schweinitz Brunner considered human communities in structural-functional terms, advocating adult education as a means of social equilibrium, moving people from role to role (and even class to class). Scientific study of societies could thus predict and plan social change. 'Verner's own views of learning became less behavioural, emphasizing change through rational discussion. ${ }^{5}$

Verner sought guidance in educational psychology from American Robert Gagné (as, later, did many of his colleagues). ${ }^{6}$ They had been friends at Florida State, and corresponded about the psychology of adult learners (in "stimulusresponse" terms). In the tradition of American scientific behaviourism, Gagné emphasized environmental stimuli and behavioural responses as fundamental evidence of learning, only reluctantly acknowledging mental or cognitive operations.' $\mathrm{He}$ had little to say about humanistic (phenomenological), gestalt, psychoanalytic, or even neurobiological approaches to psychology. Gagné saw his views as applicable to adults as well as to children, but Verner disagreed. ${ }^{8}$

${ }^{2}$ UBC Archives, Verner Fonds, Box 6-4, Course notes for "Anthropology and Education" in John Friesen's handwriting. Friesen had been through the adult education doctorate programme only three years before Verner.

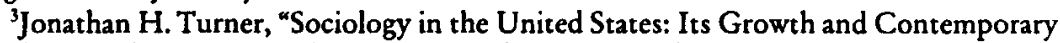
Profile," in Nikolai Genov, ed., National Traditions in Sociology (London: Sage Publications Ltd., 1989), 220-42.

"Wilbur C. Hallenbeck, "Edmund deSchweinitz Brunner: 1889-1973," Adult Leadership 22 (February 1974): 254; Edmund de S. Brunner and Wilbur Hallenbeck, American Society: Urban and Rural Pattems (New York: Harper and Brothers, 1955).

${ }^{5}$ Lowry Nelson, Charles E. Ramsey, and Verner, Community Structure and Change (New York: Macmillan Company, 1960); Verner, A Conceptual Scheme for the Identification and Classification of Processes for Adult Education (Chicago: Adult Education Association of the U.S.A., 1962), 2.

${ }^{6}$ Author's Personal Collection (hereafter PC), Comprehensive exam folder, "Reading List for Comprehensive Examination in Adult Education; PC, Curriculum folder 2, Course Outline, Education 518, 1981-1982 [Boshier]; Verner Fonds Box 6-8, Outline [1966], Education 518; John Collins, 8 June 2000, Personal Correspondence.

${ }^{7}$ Gagné, The Conditions of Learning, 1st ed. (New York: Holt, Rinehart and Winston, 1965). By the fourth edition, Gagné had modified some of his views. See also his Essentials of Learning for Instruction (Hinsdale: The Dryden Press, 1974).

${ }^{8}$ Verner Fonds, Box 7-10, 8 March 1972, Verner to Gagné; Box 7-11, 10 April 1974, Verner to Gagné; 26 April 1974, Gagné to Verner. 
These views of sociology and psychology emphasized environmental conditions required to achieve learning objectives. Verner's nomination in 1959 as a Fellow of the Centre For Advanced Study in the Behavioural Sciences by Ralph Tyler suggests his commitment to the "scientific curriculum." Not coincidentally, Tyler was on the publication board of Verner's textbook Adult Education, and Gagné shared this educational perspective."

The "scientific curriculum" has been criticized for disregarding the values, politics, or philosophical views of the educator. Certainly Verner published little about the specific ends to which adult education should be put. He wrote vaguely of cooperative goal-setting and democracy, or how adult education might oppose conservative political movements like the John Birch Society or McCarthyism, and he associated with such well-known Canadian social democrats as Leonard Marsh and Stanley Knowles. ${ }^{10}$ But by the time Verner settled in Vancouver, whatever social values informed adult education had become a quiet background against which he pursued his goals: to create and to teach a scientific discipline of adult education.

Verner sought educational theory in educational "method." In 1959 he began publishing articles and booklets on a conceptual scheme for adult education for unspecified "use" to practitioners. " Verner defined adult education as learning directed by an educator working for an organization. The educator cooperated with the learner to set learning objectives, but subsequently controlled organization of learners ("methods"), forms of instruction ("techniques"), and gadgets and other physical tools ("devices") used to achieve those goals. He excluded selfdirected learning from adult education, justifying various educational objectives through vague appeals to the values of "American society." Verner re-published his "theory of method" several times, and referred to it constantly.

Verner's theory emphasized the power to "describe, predict, and control" education. He sought to measure learning under different conditions in order to predict what would be effective, and for whom. His theory of method was geared

'Verner Fonds, Box 1-5, 26 February 1959, Tyler to Verner; Herbert M. Kliebard, "The Tyler Rationale," chap. in Forging the American Curriculum (New York: Routledge, 1992); Verner and Allan Booth, Adult Education (Washington: Centre for Applied Research in Education, 1964); Ralph W. Tyler, Gagné, and Michael Scriven, eds., Perspectives of Curriculum Evaluation, American Educational Research Association Monograph Series on Curriculum Evaluation (Chicago: Rand McNally, 1967).

${ }^{10}$ Verner Fonds Box 12-13, 17 March 1955, address by Verner; Box 1-13, transcripts; "Escape from bare facts purpose of space probe," Ubyssey (Vancouver) 6 March 1962, 4. Many American adult educators opposed the politics of Senator McCarthy: Joseph F. Kett, The Pursuit of Knowledge Under Difficulties (Stanford: Stanford University Press, 1994), 425; Verner Fonds, Box 4-44, Appointment Diary, 21 and 28 November 1959; 20 and 25 January 1960, 17 April 1960; UBC Reports 12, 4 (September-October 1966).

"Verner, A Conceptual Scheme for the Identification and Classification of Processes for Adult Education (Tallahasee: Florida State University, 1959); also in Edmund de S. Brunner et al., An Overview of Adult Education Research (Chicago: Adult Education Association of the U.S.A., 1959). 
to procedural questions: Given certain objectives, what forms of organization (methods), instruction (techniques), and gadgets (devices) were most effective, and how could this efficacy be demonstrated (evaluated)? His answers included conceptual models, precise definitions of concepts, operationalization of concepts, accurate measurement, proper analysis, and adequate testing of hypotheses. Social surveys would reveal forms of social organization or structures familiar and acceptable to a given population-hence the method appropriate for that population - and identify social or personal deficiencies implying educational goals. Having understood participants' characteristics, and tested instructional forms, the educator could choose the most effective techniques (and devices). Even questions about how education might alleviate poverty were reduced to questions about which educational "methods" were appropriate to impoverished subcultures. ${ }^{12}$

Verner's ideas-in textbooks, in contracted research in agricultural extension, in socio-economic surveys, in studies for the Canadian Labour Congress, and in Kellogg reports on continuing nursing education - fit the conservative outlook of British Columbians. ${ }^{13}$ S. N. F. Chant's 1960 Royal Commission on Education had preferred academic studies and a discipline-centred pedagogy over the childcentred pedagogy of progressive education then popular among British Columbia educationists, including UBC's Dean of Education Neville Scarfe. ${ }^{14}$ Verner's support of the scientific curriculum and interest in managing adult learning by developing a "discipline" of adult education fit this conservative mood, although he promoted himself with progressive rhetoric, ${ }^{15}$ thus appearing a "scientific management progressive" rather than a "social reform progressive."

\footnotetext{
${ }^{12}$ Verner, "Cultural Factors and Communication,"Adult Leadership 18 (March 1970): $268-70,298$.

${ }^{13}$ Verner and Peter M. Gubbels, The Adoption or Rejection of Innovations by Dairy Farm Operators in the Lower Fraser Valley (Ottawa: Agricultural Economics Research Council of Canada, 1967), 59; Verner and Gary Dickinson, Community Structure and Participation in Adult Education (Ottawa: Department of Regional Economic Expansion, 1971), 2, 38-9; Dickinson and Verner, Education Within the Canadian Labour Congress, (Vancouver: Adult Education Research Centre, 1973); June Nakamoto and Verner, Continuing Education in Medicine, W.P. Kellogg Project Report \#3 (Vancouver: Adult Education Research Centre and Division of Continuing Education in the Health Sciences, 1972), 6-7.

${ }^{14}$ Penney Clark, “'Take It Away, Youth!' Visions of Canadian Identity in B.C. Social Studies Textbooks, 1925-1989” (Ph. D. thesis, University of British Columbia, 1996), 124. Jean Barman and Neil Sutherland, "Royal Commission Retrospective," in Barman, Sutherland, and J. Donald Wilson, eds., Children, Teachers, and Schools, (Calgary: Detselig, 1995), 411-26.

${ }^{15}$ Kett, The Pursuit of Knowledge, chap. 10.

${ }^{16}$ Herbert M. Kliebard, "The Rise of Scientific Curriculum Making," chapter in Forging the American Curriculum; Amy von Heyking "Selling Progressive Education to Albertans 1935-1953" in Historical Studies in Education/Reoued'bistoire de l'éducation 10 (Spring/Fall 1998), 67; Jean Mann, "G. M. Weir and H. B. King: Progressive Education or Education for the Progressive State?" in J. Donald Wilson and David C. Jones, eds. Schooling and Society in Twentieth Century British Columbia (Calgary: Detselig Enterprises, 1980), 91-118.
} 
Adult Education Faculty Appointments, 1957-1985

\begin{tabular}{lccccc} 
& Appointed & Rank & Tenure & Promotion & Departure \\
\hline Allan Thomas & 1956 & Instructor II & - & $1959^{\dagger}$ & 1961 \\
Coolie Verner & 1961 & Professor & 1961 & $\mathrm{n} / \mathrm{a}$ & 1977 \\
Russell Whaley & 1965 & Asst Prof & - & - & 1966 \\
John Niemi & 1966 & Asst Prof & 1969 & 1971 & 1974 \\
James Thornton & 1969 & Asst Prof & 1974 & 1990 & 1991 \\
Gary Dickinson & 1969 & p/t Asst & 1980 & $1971,1977^{*}$ & 1981 \\
Gordon Selman & 1974 & Assoc Prof & 1974 & - & 1992 \\
Roger Boshier & 1974 & Asst Prof & 1978 & 1978,1982 & $\mathrm{n} / \mathrm{a}$ \\
John Collins & 1976 & Asst Prof & - & - & 1979 \\
Dale Rusnell & 1975 & Asst Prof & - & - & 1981 \\
Daniel Pratt & 1976 & Asst Prof & 1976 & $1992 / 1998$ & $\mathrm{n} / \mathrm{a}$ \\
William Griffith & 1977 & Professor & 1977 & $\mathrm{n} / \mathrm{a}$ & 1996 \\
Peter Cookson & 1979 & Asst Prof & - & - & 1984 \\
Paz Buttedahl & 1982 & Instructor & - & $1984^{\dagger}$ & 1986 \\
Tom Sork & 1981 & Asst Prof & 1986 & 1991,1998 & $\mathrm{n} / \mathrm{a}$ \\
Kjell Rubenson & 1982 & Professor & 1982 & $\mathrm{n} / \mathrm{a}$ & $\mathrm{n} / \mathrm{a}$ \\
\hline & & & & &
\end{tabular}

† Promotion to Assistant Professor

* Dickinson was promoted from Assistant to Lecturer in 1971, to Assistant Professor in 1972, and Associate Professor in 1977.

Does not include Visiting appointments.

Sources: UBC Calendars; Curriculum Vitae; Personal Correspondence; BoG Minutes; Faculty of Education Collection (passim). 
Adult education colleagues in the United States were hostile to Verner's views. He was well-known through articles, book reviews, and editorials in Adult Education, and as a founder of the Commission of Professors of the Adult Education Association of the U.S.A. Even so, few were impressed with his conceptual scheme. Academic colleagues criticized or simply ignored Verner's scheme, at best calling it a "thoughtful" potential fillip for discussion, and warning against his hazardously "heavy-handed" approach. ${ }^{17}$ Many saw Verner's views as dogmatic, narrow, and controlling. ${ }^{18}$

Such could not be the case at UBC, where for many years Verner was the sole department member. Students absorbed his views on adult education in courses and as research assistants and participants in a well-established departmental culture. Although classroom discussions of the purposes of adult education and the values of a democratic society were common in the 1960s and 1970s, students uniformly learned to conceptualize the field of adult education and to conduct research according to Verner's scheme. ${ }^{19}$

Theory, properly used, directed practice."Methods of Adult Education," the single required course for all adult education programmes until 1981, began with the social desirability of adult education, then quickly moved to definitions of learning and learning theory. The bulk of the course followed Verner's conceptual scheme. 20

Verner's views dominated his other courses. In his original 1961 correspondence version of "Introduction to Adult Education," Verner promoted the field as a cooperatively planned and learner-centred "leading social movement in modern society." Verner provided opportunities for students to indicate their "immediate needs," but led them to a scientific view of education dependent on

\footnotetext{
${ }^{17}$ Verner Fonds, Box 9-5, MS, Review of "Adult Education Theory and Method." Burton W. Kreitlow, "Needed Research," Review of Educational Research 35, 2 (June 1965): 241. Robert A. Carlson, "Professionalization of Adult Education: An Historical-Philosophical Analysis," Adult Education 28 (Fall 1977): 53-63; William S. Griffith, "The Impact of Intellectual Leadership," chap. in John Peters, Peter Jarvis and Associates, eds., Adult Education: Evolution and Acbievements in a Developing Field of Study (San Francisco: Jossey-Bass, 1991), 108; Kjell Rubenson, "Adult Education Research: In Quest of a Map of the Territory" Adult Education 32 (1982): 57-74; Alan B. Knox, review of Verner's Adult Education Theory and Method: A Conceptual Scheme for the Identification and Classification of Processes in Adult Education 13 (Summer 1963): 253.

${ }^{18}$ Verner Fonds, Box 8-14, A. H. Charnley, review manuscript of Dickinson's "Principle Contributions to a Discipline of Adult Education;" Robert Carlson, "The Nature of Adult Education" in Phyllis M. Cunningham, ed., Yearbook of Adult and Continuing Education(Chicago: Marquis Academic Media, 1980), 82-85. Perhaps ironically, this is what Verner objected to in youth schooling: see his review of Compulsory Mis-Education by Paul Goodman in Adult Education 17, 1 (Autumn 1966), 49.

${ }^{19}$ Personal correspondence, Dale Rusnell, 24 May 2000; personal correspondence, Glenn Hardy, June 17, 2000.

${ }^{20}$ Verner Fonds, Box 6-8, Course Outline [1967]; Pioneering a Profession (Vancouver: Adult Education Research Centre, UBC, 1973), 45, Verner Fonds, Box 6-8, Outline Education 518, [1967-8]
} 
social science research and on what he promoted as the "discipline" of adult education. On programme planning, he wrote:

Our knowledge in this area is severely limited. We have yet to learn how to design efficient programmes for certain specified adult learning tasks. As a result, we are not as efficient, economical, and effective as we may become... if we achieve this knowledge about programme planning and if we can apply it to the adult education situation, we can anticipate a complete revolution in adult education. ${ }^{21}$ The revised 1964 correspondence course "Introduction to Adult Education" reiterated these sentiments with considerably more booster rhetoric and opportunities for student opinions. Subsequent correspondence versions remained essentially unchanged until the late $1970 \mathrm{~s}^{22}$

Students readily incorporated Verner's views and conceptual model in major papers and theses, agricultural extension adoption studies, historical and institutional studies, and evaluation studies, particularly during the 1960 s and early 1970s. Early theses not closely tied to "methods, techniques, and devices" remained consistent with Verner's views by examining institutions or educators. Non-institutional studies such as literature reviews assumed for purposes of exposition that educators always knowingly played active parts in managing adult education. Verner's methodologcial preferences dominated studies on participation, which became indirect studies of "methods." Even social reform-minded students like Darrell Anderson and long-time political activist Daisy Webster wrote theses in Verner's terms.

Graduate theses of the 1960s relied on hypothetico-deductive methodology and on statistical data analysis almost exclusively. The first "cohort" of doctoral students in 1972 accepted adult education as a "discipline," in light of its literature, research, and knowledge base, despite its want of theory or strong scientific foundation. The department should, the students thought, continue to create knowledge "exclusive to adult education. ${ }^{\text {"23 }}$ By 1973 socio-economic surveys comprised the largest category of non-degree research. 1974 doctoral students were expected to learn "scientific method and parametric/non-parametric statistics to solve problems in the practice of adult education. ${ }^{\text {24 }}$

Faculty and students down-played self-directed learning and linked adult education to deliberate provision by educators. ${ }^{25}$ In 1973 , graduate students helping to write the departmental retrospective Pioneering a Profession reiterated Verner's views in vague statements. After Verner retired in 1977, doctoral students requested his continuing supervision, referring to him as the "most eminent

${ }^{21}$ UBC, Coolie Verner Memorial Reading Room (hereafter CVMRR), Education 412 (Correspondence), Verner [1961]. The course lacks page numbers.

${ }^{22}$ CVMRR, Education 412 (Correspondence), Verner [1961]; Verner/Cameron, 1964; Davison 1972; Thornton/Little 1977; Verner Fonds, Box 6-8, Contemplated Course Outline, Education 412, [1975].

${ }^{23}$ PC, Curriculum folder 2, "Goals for the Adult Education Department," 1972, 6, 15, 16.

${ }^{24}$ Verner Fonds, Box 6-7, October 1974, "Programmes of Study in Adult Education."

${ }^{25}$ Gary Dickinson, ed., Adult Education in British Columbia (Vancouver: Adult Education Research Centre, 1973). 
professor of adult education in Canada. ${ }^{\text {26 }}$ One such student, David Little, published a paper recreating Verner's conceptual scheme in considerable detail. ${ }^{27}$

The Faculty of Graduate Studies in the early 1960 s required research materials be made available for advanced studies. ${ }^{28}$ Because library classification schemes had no category for adult education (a situation Verner found intolerable), he demanded as a condition of tenure that UBC move his personal library from Florida. ${ }^{29}$

Verner was keen to publish and to catalogue research. He co-published a bibliography of local adult education research in 1963, and in 1964 edited a special edition of his faculty's Joumal of Education of the Faculty of Education. The latter contained a bibliography of some eighty-seven studies, many pre-dating Verner, and included social work theses, articles from trade journals, and studies by education administrators, politicians, and various social researchers. The department published another bibliography in 1968, and a second adult education issue of the Faculty journal in 1971. This time, the bibliography listed some 143 items restricted to academic articles published under the adult education label. In 1977, UBC adult education professors produced yet another "checklist" of publications, adding further "evidence" of a growing discipline and a professional knowledge base. ${ }^{30}$

Verner wrote prolifically for a narrow audience. Apart from contracted reports and historical cartography papers (an avocation), his publishers were closely and professionally identified with adult education. Verner insisted his education doctorate was as respectable as any $\mathrm{PhD}$ in sociology and that he was entitled to join the American Sociology Association, but never published in sociology journals. ${ }^{31}$ The Adult Education Association of the USA (and its successor the American Association of Adult and Continuing Education) published many of Verner's works, either in their journal Adult Education or as booklets.

${ }^{26}$ Verner Fonds, Box 3-3, 11 April 1977, memo to Chairman, Department of Adult Education.

${ }^{27} \mathrm{PC}$, Research Folder, David Little, "Adult Learning and Education." Reprinted as “Adult Learning and Education: A Concept Analysis" in Cunningham, ed., Yearbook of Adult and Continuing Education (Chicago: Marquis Academic Media, 1979), 3-19.

${ }^{28}$ FoGS Deans Office, Box 1-1, January 1961, "Report of the Committee on Graduate Degrees in the Faculty of Education."

${ }^{29}$ Verner Fonds, Box 1-6; 7 March 1961, Verner to Friesen.

${ }^{30}$ Margarett M. Stott and Verner, A Trial Bibliography of Research Pertaining to Adult Education (Vancouver. Extension Department, University of British Columbia, 1963); Dickinson, Contributions to a Discipline of Adult Education, 45; Verner, ed., "Adult Education in British Columbia,"Joumal of Education of the Faculty of Education of the University of British Columbia 10 (1964); Dickinson, Research Related to Adult Edcuation Conducted at the University of British Columbia (Vancouver: Faculty of Education, 1968); James Thornton, ed., "Special Issue on Adult Education in B.C.," Journal of Education of the Faculty of Education 18 (Winter 1971); Roger Boshier, Bonnie Jean Thiesfeld, and Dickinson, A Checklist of Studies by Adult Educators in the Pacific Northwest (Vancouver: Northwest Adult Education Association, 1978), based on an earlier list by Dickinson.

${ }^{31}$ Verner Fonds, Box 3-5, 25 January 1963, [Brunner]. 
Most of Verner's other work was issued by UBC, The Faculty of Education, and the department itself (the "Adult Education Research Centre"); only a few minor papers appeared in wider education journals and agricultural economics journals. Many publications were re-workings of the same theme and he quoted himself often. ${ }^{32}$

Verner enjoyed close academic links with a small academic community in the United States, but had little intellectual exchange with professors in his own institution. He reinforced this tendency by staffing his department with likeminded colleagues.

The first new faculty appointment Russell Whaley, an American with a Master of Public Health degree from the University of Michigan and a $\mathrm{PhD}$ from Wisconsin, arrived in 1965 but stayed hardly long enough to make an impression. His proclivity for quantitative, hypothetico-deductive research suggests affinities with Verner's educational views. ${ }^{33} \mathrm{His}$ main contribution was in securing funding for a study on disadvantaged adults. ${ }^{34}$

John Niemi, an American with an education doctorate from the University of California (Los Angeles), joined the department in 1966. He worked with students on survey research, and on social philosophy, the educationally disadvantaged, and the social role of adult education (to which he brought social gospel sensibilities). ${ }^{35}$ Unlike Verner, Niemi took a strong interest in broadcast media. He taught the popular "Mass Media and Communications" (a course predating Verner, and one to which Verner paid little administrative heed) ${ }^{36} \mathrm{Niemi}$ published well over a dozen articles in professional journals between 1969 and 1971 , but these efforts went unrecognized in his own department: only two coauthored articles were mentioned in the 1971 Journal of Education of the Faculty of Education. ${ }^{37}$ Niemi's publications-mainly opinion pieces and book reviewswere not the empirical studies typical of Verner's research, and his view of research differed fundamentally to Verner's.

Niemi sided with critics who suggested excessive reliance on adult education implied personal deficiency. ${ }^{38}$ Wary of "administrative priority," reliance on

${ }^{32}$ For example, Verner, "Research," Food For Thought 16, 5 (February 1956): 214-21; "U.S. Research Review,"Adult Education (U.K.) 28 (1956): 315-21; “Research-Based Publications, 1955" Adult Education 6, 4 (Summer 1956): 226-33.

${ }^{33}$ R. F. Whaley and T. Adolph, "Attitudes Toward Adult Education," Adult Education 17 (Spring 1967): 152-6.

34“Professors Analyze Poverty Literature," UBC Reports, 12, 4 (September-October 1966), 3.

${ }^{35}$ Dickinson, Research Related to Adult Education Conducted at the University of British Columbia; University of British Columbia, Lutheran Campus Centre Archives, Current Files/LSM/UBC General Folder, Membership lists 1968, 1972; Chaplain's Report 1968-69.

${ }^{36} \mathrm{PC}$, Annual Reports, 1967-1970.

${ }^{37} \mathrm{PC}$, Annual Reports, 1967-1972.

${ }^{38}$ John Ohliger, “Adult Education: 1984," Adult Leadership 19,7 (January 1971): 223-4; and "Is lifelong adult education a guarantee of permanent inadequacy," Convergence 7,2 (1974): 47-59. 
experts, and the privileges of the economically or politically powerful, ${ }^{39}$ he joined those who saw adult education in danger of domination by empirical researchers with an excessively narrow view of research and the field of adult education. Niemi consequently lost influence in the department. In 1971, "Mass Media" was replaced as a degree requirement by a colleague's course on programme planning. According to Niemi, Verner deliberately and autocratically demoted the media course and re-assigned students. ${ }^{10}$

Although Niemi served on most master's thesis committees with Verner between 1967 and 1970 - and was the sole adult education faculty member for some half dozen-he served on only two from 1970 to 1975 . Course descriptions in Pioneering a Profession presented "Mass Media" in Verner's terms (as educational devices). Niemi retained responsibility for the diploma programme, a role that minimized his research and intellectual leadership. ${ }^{41}$ Whether the rift with Verner was personal or professional-or both-Niemi was given little opportunity to influence the department's research or curricular orientation. ${ }^{42}$

What student research Niemi did supervise often fit standard department practice. He was principal research supervisor of the department's first female doctoral graduate-but on a Verner-inspired, agency-based survey of how nursing educators could increase effectiveness through deliberate knowledge dispersal. ${ }^{43} \mathrm{Niemi}$ co-published with students, and edited a book on media incorporating accounts of his class and contributions by his students, but these were popular, non-academic works. ${ }^{44}$ Despite promotion, tenure, and friends in the Faculty, Niemi returned to the United States in 1974 to work for the Education Resource Clearinghouse.

Gary Dickinson, by contrast, held views consistent with Verner's and exercised considerable influence in the department during the 1970s. Recruited in 1965, he had been Verner's magistral and first UBC doctoral student, then became research director for a series of federally funded socio-economic surveys.

${ }^{39}$ Niemi, "Cults and Their Captives-A Plan of Escape," Adult Leadership 20, 10 (April 1972): 360; Jerold Apps "Toward a Broader Definition of Research," Adult Education 23, 1 (Fall 1972): 59-64; Robert Carlson, "The Nature of Adult Education" in Cunningham, ed., Yearbook of Adult and Continuing Education (Chicago: Marquis Academic Media, 1980), 82-6; Verner Fonds, Box 7-11, 28 March 1974, Verner to Knowles. Carlson admitted Verner expressed different views in person.

${ }^{40}$ Faculty of Education Fonds, Graduate Board/Graduate Division Working Committee/ Executive Committee Binder 1965-1978, 28 September 1971, “Submission to the Graduate Board" by Niemi.

"PC, Annual Report 1971-1972.

${ }^{42}$ Gordon Selman, Felt Along the Heart: A Life in Adult Education (Vancouver: Centre for Continuing Education, UBC, 1994), 139-140.

${ }^{43}$ Beverly Du Gas, "An Analysis of Certain Factors in the Diffusion of Innovations in Nursing Practice in the Public General Hospitals of the Province of British Columbia” EdD thesis, University of British Columbia, 1969.

"Niemi, ed., Mass Media and Adult Education (Englewood Cliffs: Educational Technology Publications, 1971); PC, Annual Report, 1970-71. 
Dickinson was the most published contributor to Adult Education from 1964 to 1973, also writing on trade union education in Canada and continuing education in the health professions ${ }^{45}$ By the late 1970 s, he had begun to write adult basic education reports and conduct surveys of under-educated adults in British Columbia.

Dickinson was thoroughly grounded in Verner's view of research, and their coauthored studies made constant reference to the senior man's "principles" of adult education. ${ }^{46}$ Like his mentor, Dickinson claimed his research contributed to the organized body of knowledge that made adult education a profession. ${ }^{47}$ Although his solo publications were not explicitly tied to Verner's conceptual models, he often wrote of the "discipline" of adult education or called for theory-building. His textbook How to Teach Adults presented adult education as consistent with Verner's maxims about institutional situations and expert teachers informed by research and theory. ${ }^{48} \mathrm{After}$ Verner retired, Dickinson urged researchers "in adult education to build upon [Verner's] framework in order to foster a mature discipline. ${ }^{\text {49 }}$

Dickinson embraced a "scientific" view of education. A 1970 paper advanced the hypothesis that "by raising the level of education of an adult, his chances for economic success are enhanced" and social alienation may thus decrease. His study found "educational attainment is inversely related to alienation." Questions about this relationship aside, Dickinson's conclusions are bromidic:

The chief role of the adult educator, therefore, would probably be to impart the notion that success is capable of achievement by the educationally disadvantaged, and that literacy and basic education offers a legitimate method for its attainment. ${ }^{50}$ These recommendations are neither logical outcomes of the study nor particularly insightful. The emphasis on studying the learner and the learner's present social context as the basis for determining educational objectives is consistent with a scientific view of curriculum. Many of the surveys done by Verner and Dickinson

\footnotetext{
${ }^{45}$ Huey B. Long and Stephen K. Agyekum, “Adult Education 1964-1973: Reflections of a Changing Discipline," Adult Education 24,2 (Winter 1974): 112. PC, Annual Report 197172; Dickinson, Robert Gobert, and Louise McGregor, "Preparing Health Professionals as Specialists in Continuing Education," Adult Leadership 24 (November 1975): 87-8, 110.

"Dickinson and Verner, Community Structure and Participation in Adult Education, special study 3, ARDA, Canada Land Inventory Project 49009 (Vancouver: Faculty of Education, UBC, 1969), 2; Dickinson and Verner, Education within the Canadian Labour Congress (Vancouver: Adult Education Research Centre, 1973), 83.

"Dickinson and Dale Rusnell, "A Content Analysis of Adult Education," Adult Education 21, 3 (Fall 1971): 177.

${ }^{18}$ Dickinson, Teacbing Adudts: $A$ Handbook for Instructors (Toronto: New Press, 1973), vii, viii; Dickinson, Teaching Adults, 68-9; Dickinson and Nicholas A. Rubidge, "Testing Knowledge About Adult Education," Adult Education 23, 4 (Summer 1973): 284, 298; Dickinson, "Research," in Pioneering a Profession, 78-9; Dickinson and Rusnell, "A Content Analysis of Adult Education," 184. The labour and health reports also contained such references.

${ }^{49}$ Dickinson, Contributions to a Discipline of Adult Education, 36.

${ }^{50}$ Dickinson, "Alienation Among Rural Adults of Low Educational Attainment" Adult Education 21 (Fall 1970): 3, 11-12.
} 
(and even Niemi's, on educational participation of underprivileged people) similarly left unanswered questions of what should be done and why. ${ }^{51}$

Dickinson advocated research and theory in the department through seminars, courses, and department publications, without ever professing a "theory" of his own ${ }^{52}$ His graduate students typically learned quantitative methods, tested hypotheses, and conducted extensive statistical analyses. Dickinson believed a "professional adult educator" should have technical knowledge and expertise, be able to use "methods, techniques, and devices," and have an ethical and responsible disposition.$^{33} \mathrm{He}$ remained concerned with objectivity, validity, and reliability, and his own research often tested hypotheses with quantified data. ${ }^{54}$

Such views naturally informed Dickinson's courses. He tested students' knowledge to answer the general question of what an adult educator should know. Answers to test questions printed in How Adults Learn indicate the pertinent topics. Behavioural objectives were central. Dickinson emphasized physiological traits accompanying aging in adult learners. "Methods, techniques, and devices" appeared in another section, and a chapter on evaluation looked at measuring the effectiveness of instruction. ${ }^{55}$

New recruit Roger Boshier, who held a $\mathrm{PhD}$ in social psychology from Wellington University, New Zealand, was equally enamoured of theory. Hired in 1974 after Verner's tour of the antipodes, Boshier took particular interest in why adults participated in education, hoping to

facilitate the growth of theory... [and] throw light on the conceptual desert that

underpins adult education dropout research, and enhance efforts to increase the quantity and quality of learning experiences for adults. ${ }^{56}$

He became well-known in the field for research into adult education participation from a psychological perspective, and an influential faculty member in his department. ${ }^{57}$ As a peace and environmental activist in New Zealand, his motives may have been partly political, and in this regard he introduced new ideas into the

${ }^{51}$ Niemi and Darrel Anderson, Adult Education and the Disadvantaged Adult (Syracuse: ERIC Clearinghouse on Adult Education, 1969); Gary Dickinson, "Adult Illiteracy in Canada and British Columbia," in Cunningham, ed., Yearbook of Adult and Continuing Education (Chicago: Marquis Academic Media, 1979), 179-84.

${ }^{52}$ PC, Annual Report 1971-72; PC Curriculum Folder 1, 14 February 1975, Schedule for Adult Education Courses; Curriculum Folder 1, Tentative Schedule of Courses, 1978-1979.

${ }^{53}$ CVMRR, Box 1-1, 2 July 1980, Dickinson to Adult Education faculty; Personal correspondence, Dickinson, 26 May 2000.

${ }^{54}$ For one example, see Dickinson and Rubidge, “Testing Knowledge." Dickinson later questioned the "validity and reliability" of department comprehensive exams. PC, Comprehensive exam folder, 6 June 1979, Memorandum, Dickinson to department colleagues.

${ }^{55}$ Dickinson and Rubidge, "Testing Knowledge;" Dickinson, Teaching Adults.

${ }^{56}$ Boshier, "Motivational Orientations of Adult Education Participants: A Factor Analytic Exploration of Houle's Typology, Adult Education 21, 2 (Winter 1971): 3.

${ }^{57}$ Boshier and Lynette Pickard, "Citation Patterns of Articles Published in Adult Education 1968-1977," Adult Education 30, no. 1 (Fall 1979): 34-51. Boshier also won the first "Imogene Oakes Award for Adult Education Research" in 1976, although it took a little self-promotion to get it! PC, Boshier folder, 25 July [1976], Boshier to [Peters]. 
department, becaming an enthusiastic promoter of non-school, adult learning in British Columbia. ${ }^{58}$

In other ways, Boshier fit academic views well-rooted in the department. He couched his research in humanistic language, but relied methodologically upon "valid and reliable" questionnaires and measurement tools, quantitative statistical analysis, hypothetico-deductive research design, and conceptual models to describe, control, and predict phenomena. He sought nomothetic, reality-describing theory that would improve incrementally with developments in measurement tools, and he incorporated aspects of Verner's conceptual scheme. ${ }^{59} \mathrm{He}$ saw himself as a researcher in the "discipline" of adult education, promoting its "unique analytic constructs" useful to understand, predict, and control adult education, and advocating practice based on the concepts revealed through research. ${ }^{60} \mathrm{He}$ embraced psychological behaviourism (though not exclusive of other "mentalist" psychological theories), and criticized historical research as impractical and nonempirical. ${ }^{61}$ Despite his publishing largely under "adult education," educational psychologists at UBC considered Boshier as among those "actively conducting their own behavioral [sic] research" who might contribute to a $\mathrm{PhD}$ in education. ${ }^{62}$

Unsurprisingly, Boshier promoted his view of adult education to students in courses and seminars, often asking students for a theory or model relevant to adult education. ${ }^{63}$ Boshier taught that the goal of adult education research (and scientific research more broadly) was to develop theory that would understand, predict, and

58" Dr. Roger Boshier wins major research award," Hawke's Bay Herald-Tribune (New Zealand), 19 November 1976. "A turnabout in learning," Vancouver Province, 10 February $1977,23$.

${ }^{59}$ Boshier, An Instrument and Conceptual Model for the Prediction and Diagnosis of Dropout from Educational Institutions (Wellington: Victoria University of Wellington Department of University Extension, 1971); Boshier, "Educational Participation and Dropour: A Theoretical Model," Adult Education 23, 4 (Summer 1973): 255-82; Boshier, "Theories and Models in Adult Education: A Plea for Pure Research," Canadian Joumal of University Continuing Education/ Revue Canadienne del 'éducation permanente universitaire 7,1 (Summer 1980), 12-18; Boshier, ed., Towards a Learning Society (Vancouver: Learning Press Ltd., 1980), 32-4.

${ }^{60} \mathrm{PC}$, Boshier Folder, 10 August 1976, Boshier to Bitmead; Boshier, Towards a Learning Society, 39; PC, Comprehensive Exam folder, 14 February 1980, Boshier to Adult Education faculty.

${ }^{61}$ Boshier, "Behaviour Modification and Contingency Management in a Graduate Adult Edcuation Programme" Adult Education 26, 1 (Fall 1975): 16-31; Boshier, review of C.D. Legge's Register of Research in Progress in Adult Education 27, 4 (Summer 1977): 231-2.

${ }^{62} \mathrm{PC}$, Boshier CV; PC, Boshier Folder, 18 January 1978, Arlin to Colleagues; FoGS Deans Office, Box 2-2 (folder 4), 15 October 1960.

${ }^{63} \mathrm{PC}$, Curriculum folder 1, Department of Adult Education Mark Distribution 1975-76, 1976-77; PC, Curriculum folder 1,1976, "Comprehensive Examination in Adult Education"; PC, Curriculum folder 2,20 September 1977, "Research in Adult Education"; PC, Curriculum folder 2, 1981-1982, Course Outline, Education 518; PC, Curriculum folder 3, 1979-1980, Course Outline, Education 514; PC, Curriculum folder 3, April 1980, Final Examination, Education 561. 
control adult learning, a view he pressed across North America. ${ }^{64}$ His students conducted similar thesis research (quantitative, hypotheses testing, statistical research), using measurement tools he had developed such as the "Educational Participation Scale" or his theories of "congruence."

Boshier reinforced Verner's views on defining the practice of adult education. He began the "Foundations" course with definitions of the field and examples in philosophical and historical literature, then considered how other academic disciplines might contribute to an understanding of adult education. Similarly, his "Methods" course embarked on a conceptual and theoretical discussion of adult education and learning, then moved to implications for teaching. ${ }^{65}$ This sequence affirms a view of adult education practice in which definitions of adult education and accompanying theory-or at least conceptual models-precede practice. That view was consistent with efforts to make the practice of adult education subservient to professional knowledge.

Boshier and Dickinson were the most active researchers in the department during the 1970s, and, like Verner, conducted empirical research in a positivistic vein-though Boshier took note of "alternate forms of adult education" promoted by such social critics as Paulo Freire and Ivan Illich. ${ }^{66}$ In many ways, adult education researchers had little choice in research approaches if they wanted peer recognition, since quantitative analysis was standard in adult education programmes across the United States, as well as more broadly in education. ${ }^{67}$ Dickinson had a long career at UBC, leaving in 1981 for an administrative job at a regional college; Boshier remained at UBC until his retirement.

Other adult education faculty members reinforced dominant views. James Thornton, an American with a PhD from the University of Michigan who joined the department in 1968, had studied under Verner's colleagues and adopted Verner's views at UBC. Thornton wrote several reviews, bibliographies, and "howto" guides presenting the familiar scientific view of education, describing "principles" of adult learning, and incorporating Verner's terminology of methods and techniques of adult education. ${ }^{68}$ Thornton taught the "characteristics of all adult learners" (emphasis in original), qualities unique to adult learners, and basic laws

${ }^{64} \mathrm{PC}$, Boshier folder, n.d., outline, Education 561; Boshier, "A Perspective on Theory and Model Development in Adult Education," paper presented to the Commission of Professors of Adult Education, Portland, Oregon, 1978.

${ }^{65} \mathrm{PC}$, Curriculum folder 3, Outline, Education 514 (Boshier), 1979-80; PC, Curriculum folder 2, Outline, Education 518 (Boshier), 1981-82.

${ }^{66}$ PC, Curriculum 2, [1976] "Undergraduate Courses in Adult Education;"

${ }^{66}$ PC, Comprehensive Exam folder, April 1978.

${ }^{67}$ Barbara J. Jain and Linda Carly, Comparison of Selected Requirements for the PhD and $E d D$ in Adult Education in North America (Champagne: University of Illinois at UrbanaChampagne, 1978), 17.

${ }^{68}$ Robert Gobert, Thornton, and Sharon Turnbull, Programme Planning Guide for Health Professions (Vancouver: Department of Adult Education/Division of Continuing Education in the Health Sciences, UBC, 1977). 
of learning stated in behavioural terms. ${ }^{69} \mathrm{His} 1977$ revision of Introduction to Adult Education used publications by Dickinson and Verner, again referring to "methods, techniques, and devices."

Thornton often supervised major papers and theses not based in statistical analysis. ${ }^{11}$ In the programme planning course which replaced Niemi's media course, he considered a wide range of social perspectives and academic disciplines, and used few of Verner's publications. ${ }^{22}$ Programme planning students nonetheless adapted Verner's conceptual scheme. ${ }^{73}$

John Collins was similarly stuck within his department's academic culture. Yet another American, with a doctorate from the University of Utah, he had been employed elsewhere at UBC since 1969 , then transferred to adult education in 1976, having earlier served as a part-time "research methodologist." An environmental psychologist cross-appointed with the Department of Psychology who had never studied "adult education," Collins relied on colleagues' publications and advice to inform his teaching. ${ }^{74}$ Student research he supervised (often with Boshier and Dickinson) was familiar quantitative research. When he was replaced in 1979, the Search Committee recommended someone with "an advanced knowledge of quantitative research methodology" because Collins had been "expert in quantitative approaches to social science research, including computer applications." ${ }^{\text {" }}$

Dale Rusnell, a doctoral student under Dickinson, became a faculty member in 1975 and stayed until 1981 . He was well versed in quantitative research methodology, and his dissertation on programme planning proposed a conceptual model tested by hypotheses and statistical analysis. ${ }^{76}$ Not surprisingly, he often worked with Boshier and Dickinson to guide student research on familiar topics, using Verner's ideas. He later replaced Thornton as the programme planning

${ }^{69} \mathrm{PC}$, curriculum folder 1, 1978, Course materials of James Thornton.

70Thornton and Little, Education 412 Correspondence Course (Vancouver: Centre for Continuing Education, The University of British Columbia, 1977).

${ }^{71}$ For example, Karen Unruh, "Issues of Concern to the Mature' Woman Career Student and Programmeme Planners in the Community College» (M. Ed. paper, University of British Columbia, 1976).

${ }_{72} \mathrm{PC}$, Curriculum Folder 1, Department of Adult Education Mark Distributions 1975-76, 1976-77; PC, Curriculum Folder 1, Tentative Schedule of Courses 1978-79; PC, Curriculum Folder 1, March 1975, Bibliography on Programme planning and Evaluation. For example, W. Bennis et al., The Planning of Change (New York: Holt Rinehart and Winston, 1969) touches on radical social change and conflict theories.

${ }^{73}$ CVMRR, Adult Education UBC Student Papers Box, "Adult Training Functions In Selected Lower Mainland Private and Public Sector Institutions" (class project for Agricultural Economics 504) 1973, Appendix C.

${ }^{74}$ Personal correspondence, John Collins, 8 June 2000; PC, Curriculum folder 1, Department of Adult Education Mark Distributions 1975-76, 1976-77; PC, Curriculum folder 1, Tentative Schedule of Courses 1978-79; Boshier et al, A Checklist of Studies, 5.

${ }^{75} \mathrm{PC}$, Minutes, Selman to Griffith, 2 October 1978.

${ }^{76}$ Dale Rusnell, "Development of an Index of Quality For the Planning of Management Training Programmes" (Ed. D. thesis, University of British Columbia, 1974). 
"expert," breaking from a strictly scientific view of education by considering the politics of programme planning and the values attached to educational research." As a graduate of the UBC programme with few publications of his own, Rusnell nonetheless largely maintained the programme's dominant characteristics.

There were notable exceptions to this homogeneous academic culture. Gordon Selman left his position as UBC Director of Extension in 1974 to join the adult education department at a time of growing student enrollment, bringing with him a reputation as an administrator, a decent salary, and tenure. Unlike his peers, Selman held only a magistral degree from UBC in history, did no statistical calculations, called for no adult education theory, and took little interest in adult education as a "discipline." He published some twenty-two articles between 1973 and 1977, mainly in professional journals, and several UBC-published monographs on the history of adult education in British Columbia and Canada. ${ }^{78} \mathrm{~A}$ selfconfessed Canadian nationalist, Selman wrote on Canadian traditions, publishing little in American journals. ${ }^{39}$

Selman's training as an historian and interest in the social purposes of adult education resembled those of Niemi, but his historical writing was celebratory and whiggish:

It is important that the record of where we have come from as a movement and as a field of professional activities be available to those who care. [If] we can get on with the task [of writing Canadian adult education history], we will increasingly be judged to be representing a field of growing maturity and competence. ${ }^{80}$ He wrote mainly on the institutions or "great men" of adult education (women rarely discussed) often associated with the Canadian Association for Adult Education and such other middle-class, anglo-Canadian projects as the Young Men's Christian Association, community colleges, or university extension. Examining adult education in Barkerville during the Cariboo gold rush, for example, he emphasized the literary and cultural societies led by local clergymen and

${ }^{7}$ Rusnell, "Decisions in the Design of Evaluation," (PC, unpublished MS, January 1978).

${ }^{78}$ Selman, Felt Along the Heart, 87; Roger Boshier et al, A Checklist of Studies, 15.

${ }^{79}$ Selman, “An Organization for the Study and Development of Adult Education," Dialogue 1,2 (1973): 51-4. (Note: published by the Canadian Association of Departments of Extension and Summer Schools in Universities.) Selman, Adult Education in Vancouver Before 1914, Occasional Papers in Continuing Eduation no. 9 (Vancouver: Department of University Extension, The University of British Columbia, 1975); PC, Selman folder, 30 December 1974, "Responses to Questionnaire on The Most Significant Canadian Developments in Adult Education."

${ }^{80} \mathrm{PC}$, Research publications folder, [1974], Selman, "Concerning the History of Adult Education in Canada," Canadian Joumal of University Continuing Education/Revue Canadienne de l'éducation permanente universitaire 1, 4 (December 1974): 24-35. 
lawyers, rather than asking how immigrant miners learned to survive in their new environment. ${ }^{81}$

Selman taught various courses, particularly "Introduction to Adult Education," "Foundations," the diploma seminar, and, in the later 1970s and into the 1980 s, the history of Canadian adult education. Because he lacked a doctorate, he worked mainly with magistral and diploma students writing historical theses or major papers. Selman's influence extended beyond the department in his work on committees at UBC and with local practitioners and their associations.

Another anomalous figure in the adult education department was Daniel Pratt, who transferred in 1976 from within the Faculty. His doctoral training at the University of Washington was in psychology rather than adult education. Familiar with quantitative, theory-building research rather than steeped in the rhetoric of adult education, Pratt spoke of "principles" of adult education, ${ }^{82}$ and expressed puzzlement that research into teacher effectiveness had yielded "little or no substantial evidence of consistent or replicable features. ${ }^{\text {"33 }}$ Contrary to Verner's Diktat, he suggested adult learning researchers might consider research on youth. ${ }^{84}$ But as a newcomer to a well-established academic culture, Pratt found little opportunity to promote such views.

Pratt taught a mixture of special courses during the 1970s, including "Media and Communications," "Introduction to Adult Education," and seminars in group dynamics. On occasion he taught "Methods" and the graduate seminar, and, after 1981 , a new undergraduate course on teaching adults. He worked on student thesis committees where dominant views prevailed, but by 1983 supported student inquiries into much more various theoretically-informed perspectives on education.

Others suggest that, practically speaking, learning occurred in the "extracurriculum. ${ }^{\text {"85 }}$ The department's physical location encouraged a distinct subculture. Verner kept an office in the Extension Department in the early 1960 s, and in 1969 moved the entire department to the unused UBC President's residence; five years later, the department relocated in an old fraternity house at the

\footnotetext{
${ }^{81}$ Selman, “Adult Education in Barkerville, 1863 to 1875," B.C. Studies 9 (Spring 1971): 38-54.

${ }^{\text {22} T a r i a ~ B h a t t i, ~ R o g e r ~ B . ~ C o r n i e r ~ a n d ~ P r a t t, ~}{ }^{\alpha}$ Applying Adult Education Principles to Conference Planning" Canadian Joumal of University Continuing Education/Revue Canadienne de l'éducation permanente universitaire 7, 1 (Summer 1980), 23-6.

${ }^{83}$ Personal correspondence, Pratt, 29 May 2000; Pratt, "Instructor Behaviour and Psychological Climate in Adult Learning, "Proceedings of the 20th Annual Adult Education Research Conference (Ann Arbor: University of Michigan, 1979), 106-15; Pratt, "The Dynamics of Continuing Education Learning Groups," Canadian Joumal of University Continuing Education/Revue Canadienne de l'éducation permanente universitaire 8,1 (Summer 1981), 26-32.

${ }^{84}$ Pratt, "Teacher Effectiveness: Future Directions for Adult Education," Proceedings of the 22nd Adult Education Research Conference (DeKalb: University of Illinois, 1981), 169-75.

${ }^{85}$ Frederick Rudolph, $A$ History of the American Undergraduate Course of Study Since 1636 (San Francisco: Jossey-Bass, 1977), 22; Faculty of Education Fonds, unfiled, Dean's Annual

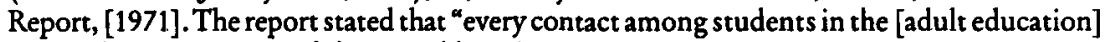
Centre becomes a part of their total learning experience."
} 
edge of campus. Here students and professors participated in social, administrative, and research activities, wrote witty celebratory odes, and challenged the Faculty admission standards. ${ }^{86}$ Inside this miniature flourishing counter-culture, Verner's authoritarian rule reinforced the formal curriculum, dampening cooperative or "progressive" learning.

Verner retired in 1977 having built a homogeneous and well-defined academic culture. Those who demurred either left or were quiet. By the mid-1970s, the department had a "core" reading list for the new comprehensive examination, a "bookshelf" of essential works, and a common exam for "Introduction to Adult Education. ${ }^{\text {"87 }}$

$* * 4$

In some ways the department was a success, praised by adult education professors in the United States and elsewhere, and sought out by a few foreign students. ${ }^{88}$ But in other respects the department was in serious trouble. UBC Faculty of Education members were scarcely aware of their adult education counterparts, and the utilitarian theory Verner promised practitioners remained elusive. ${ }^{89}$ Even as Verner retired, a new administrative regime began to question the teaching and research of the adult education department, just as challenges to dominant social and educational thought swept across North America and even into UBC. ${ }^{90}$

William Griffith arrived from the University of Chicago in 1977 to replace Verner and effected various changes demanded by university and Faculty administrators. ${ }^{1}$ He had studied agricultural science before earning a Chicago $\mathrm{PhD}$ in adult education, and differed from Verner's academic orientation in several key ways. Griffith often wrote of the polities rather than the science of adult educa-

${ }^{86}$ Verner Fonds, Box 7-10, [early 1970s], poem; PC, Boshier folder, 12 February 1976, Keith to Boshier; PC, Curriculum folder 2, 8 June 1977, Schroeder to Thornton.

${ }^{87} \mathrm{PC}$, Curriculum folder 1, "Reading list for comprehensive examination in adult education," [1977]; Boshier, "History and Significance of the Coolie Verner Reading Room at The University of B.C." unpublished MS, 1992; Personal correspondence, Rusnell, 24 May 2000.

${ }^{*}$ Boshier demonstrated that the most cited adult education researcher in Adult Education in a ten year period was Boshier himself. Verner came fourth, and Dickinson eighth. Boshier, "Citation Patterns of Articles Published in Adult Education 1968-1977," Adult Education 30, no. 1 (Fall 1979): 34-51.

'Personal correspondence, John Dennison, 23 May 2000; Faculty of Education Fonds, Dean's Advisory Committee Personnel Binder, Minutes, 23 November 1982, 9 December 1982, 20 January 1983; Verner, "Some Reflections on Graduate Professional Education in Adult Education," The Canadian Joumal of Higher Education 8,2 (1978):47; Personal correspondence, John Collins, 8 June 2000.

${ }^{90}$ Jerold W. Apps, “Toward a Broader Definition of Research;" Harold Perkin, "The Historical Perspective" in Burton Clark, ed., Perspectives on Higher Education (Berkeley and Los Angeles: University of California Press, 1984), 17-55; John Andrews and W. Todd. Rogers, eds., Canadian Research in Education: A State of the Art Review (Ottawa: Minister of Supply and Services, 1982).

${ }^{91}$ CVMRR, Field Advisory Committee Binder, 12 January 1981, Griffith to Blaney. 
tion, and of the inherently political role of the educator. ${ }^{92}$ Although he used questionnaires and statistical analysis, Griffith accepted a wide range of research approaches, eschewing only politically explicit "action-oriented" research. ${ }^{93} \mathrm{In}$ 1979, he asked why adult educators were dissatisfied with traditional research:

Some research is pursued using inappropriate methodologies borrowed from the physical or biological sciences which are incapable of dealing with the variables under consideration... some research is aimed at adding to the body of tested knowledge even though the questions asked and the variables measured are unrelated to improving the quality of human life... some research is performed in ways that hinder rather than facilitate the utilization of the results by the individuals whose lives and environment were studied during the research.... ${ }^{94}$ This critique might have been aimed directly at UBC adult education research.

As a tenured professor and department or divisional chair for his first few years at UBC, Griffith sought to broaden the research and educational climate. Questioning the monopoly of quantitative inquiry, he reminded his colleagues

[T] here is no best research methodology... there is no dogmatic or doctrinaire position taken by the Department of this Faculty with regard to the various kinds of research which may be pursued in major papers, M. A. theses and Ed. D. dissertations. ${ }^{95}$

Despite Griffith's modest reforms, the familiar quantitative research continued. Dickinson conducted more surveys and wrote reports, often relevant to his new role in coordinating the Adult Basic Education Consortium, but left the department in $1981 .{ }^{96}$ Boshier still worked to find "valid and reliable" ways to measure or predict educational participation, with students and in his prison education. ${ }^{97}$ Collins left in 1979, but did research as a private consultant.

${ }^{92}$ William S. Griffith, "The Role of Public School Adult Education," The High School Journal 49, 2 (November 1965): 58. Copy in personal collection. William S. Griffith and Ronald M. Cervero, "The Adult Performance Level Programme: A Serious and Deliberate Examination," Adult Education 27,4 (Summer 1977): 209-24. Griffith and Cervero questioned merits of the scientific curriculum. Griffith, "Educational Needs: Definition, Assessment, and Utilization," School Review (May 1978): 393 (382-94).

${ }^{93}$ Griffith and Mary C. Cristarella, "Participatory Research: Should it Be a New Methodology for Adult Educators?" in Niemi, ed., Viewpoints on Adult Education Researcb (Columbus: ERIC Clearinghouse on Adult, Career, and Vocational Education, 1979), 15-42; Lutaf Dhanidina and Griffith, “Costs and Benefits of Delayed High School Completion," Adult Education 25, (Summer 1975): 217-30.

${ }^{94}$ Griffith, “Adult Education Research-Emerging Developments," Studies in Adult Education 11 (October 1979): 125-6.

${ }^{95}$ PC, Curriculum folder 3, 8 September 1977, Griffith to Boshier; 17March 1978, Griffith to Department.

${ }^{9}$ Dickinson, "Educationally Disadvantaged Adults in Canada," Adult Literacy and Basic Education 2, 2 (Summer 1978): 83-9; Dickinson, The Undereducated of British Columbia (Vancouver: Adult Education Research Centre, 1978).

97Boshier, Education Inside: Participation in Prison Education Programmes (Vancouver: UBC Programme for Correctional Education Research and Training/Solicitor General of Canada, 1983). 
Newcomer Peter Cookson, Griffith's doctoral student at Chicago, defended his quantitative research against phenomenological criticisms. ${ }^{98} \mathrm{He}$ was also busy with the adult basic education projects, writing several reports, and contributing to the prison education project. ${ }^{\text {" }}$ He offered the "Foundations" course, dwelling on the values and moral ends of adult education. (This deviation from a strictly scientific view of education prompted student complaints of excessive "moralizing. ${ }^{\text {"100 }) ~ S t u d e n t s ~ u n d e r ~ C o o k s o n ' s ~ s u p e r v i s i o n ~ a d v o c a t e d ~ s c i e n c e ~ l i t e r a r y ~ o r ~}$ used quantitative methods to predict behaviour. ${ }^{101}$

Meanwhile, Thornton's research took an interdisciplinary turn. In 1977, he had been encouraged to join the UBC gerontology committee, and in the early 1980 s he promoted gerontology as a field, potentially a discipline and career option. ${ }^{102}$ Thornton presented papers at gerontology conferences and wrote various reports to promote his vision of academic gerontology. As Chair of the committee, he worked with researchers from across UBC who encouraged a multi-disciplinary approach. ${ }^{103}$ Thornton began teaching educational gerontology courses, and in 1982 discussed an interdepartmental PhD in cooperation with the departments of psychology, philosophy, home economics, and others. ${ }^{104}$ Although Thornton's conception of research or its significance for aspiring professional adult educators may not have changed significantly, his new work did not seek adult education theory.

Selman continued to write history of Canadian adult education, and, consistent with requests from those working in the field, encouraged student

${ }^{98}$ Peter S. Cookson, “Determinants of Adult Education Participation of Low Income Adults," Proceedings of the 24th Adult Education Research Conference (Montréal: Concordia University, 1983), 69-74.

${ }^{99}$ Cookson, The National Adult Basic Education Institute: Report and Recommendations (Vancouver: Adult Education Research Centre, 1982).

${ }^{100} \mathrm{PC}$, Curriculum folder 3, 10 May 1982, Hills to Griffith; Faculty of Education Fonds, unfiled, Faculty of Education Annual Teaching Evaluation Reports.

${ }^{101}$ José A. Molina, "Occupational Conditions As Predictors of Adult Education Participation" (M.A. thesis, University of British Columbia, 1984); Gerald Denis Paradis, "Science Literacy and Adult Education-Curriculum for the Future" (M.Ed. paper, University of British Columbia, 1983).

${ }^{102}$ Verner Fonds, Box 3-3, 2 December 1977, Griffith to Verner; Thornton, "Issues Affecting Gerontology Education and Manpower Needs in Population Aging," Canadian Joumal on Aging 2 (November 1983): 153-61. Thornton characterized gerontology as a discipline in the same vague terms Verner used to promote adult education.

${ }^{103}$ Thornton, "An Aging Population in Aging Communities: The challenge to the university," Proceedings of a Research Workshop on an Aging Population in Aging Communities, vol. 3 (Vancouver: Centre for Human Settlements, University of British Columbia, 1981), 7. See also Thornton, "The Abolition of Mandatory Retirement: Issues emerging in the debate," Greying Western Canada: The Second Research Workshop on an Aging Population in Aging Communities. An Older Workforce: Aspects and Policy Implications, vol. 2 (Vancouver: Centre for Human Settlements, University of British Columbia, 1983), 25-37.

${ }^{104}$ CVMRR, Box 3-3, Minutes, 8 September 1982; Box 1-3, December 1982, Course Proposals in Educational Gerontology. 
historical research and policy analysis. ${ }^{105}$ One of his magistral students writing a biography of a local adult educator still referred to "principles of learning" appropriate to teaching adults. ${ }^{106}$ Selman (with others in the department) helped to launch the Canadian Association for the Study of Adult Education and what would become The Canadian Joumal for the Study of Adult Education/la Revue canadienne pour l'étude del'éducation des adultes as part of a more general effort to "Canadianize" the social sciences and academia. ${ }^{107}$ In the early 1980 s, the Social Science Federation of Canada admitted "interdisciplinary" learned societies, including adult education in $1983 .{ }^{108}$

Selman encouraged the growing body of critically-minded students in 1983 when he suggested a course in feminism be taught by educational sociologist and colleague Jane Gaskell. ${ }^{109} \mathrm{His}$ concern for the social values pursued by adult educators show in the 1985 correspondence course "The Community Practice of Adult Education." The author, social worker Michael Clague, thanked Selman (for unspecified reasons) and aligned the course explicitly with 'the 'social movement' conception of adult education." Rather than emphasize educational method or generalizable knowledge, Clague discussed the politics, economics, and social context of adult education, and the values and goals of adult educators. ${ }^{10}$

The widespread critique of social and educational thought of the early $1980 \mathrm{~s}$ had significant impact on learning theory. Pratt took interest in a new approach to adult learning, one in keeping with his background in humanistic psychology. ${ }^{111} \mathrm{He}$ became more critical of popular notions about adult learning, and considered "intentions and purpose rather than behavior [sic] or skills" and the expectations of students and instructors. ${ }^{112} \mathrm{He}$ adopted phenomenological research methodologies and conceptions of theory. Student interest encouraged

\footnotetext{
${ }^{105}$ CVMRR, Box 1-3, 30 June 1983, Gord to Tom (Selman to Sork).

${ }^{106}$ Reva Kalef, "Betsy McDonald: Adult Educator" (M. Ed. thesis, University of British Columbia, 1984).

${ }^{107}$ Andrews and Rogers, Canadian Research in Education, 19; S. D. Clark, "Sociology in Canada: an historical overview," Canadian Journal of Sociology 1, no. 2 (1975): 225-34; Harry H. Hiller, "The Canadian Sociology Movement: analysis and assessment," Canadian Journal of Sociology/Cabiers canadienne de sociologie 4, 2 (1979): 125-50.

${ }^{108}$ Donald Fisher, The Social Sciences in Canada: 50 Years of National Activity by the Social Science Federation of Canada (Waterloo: Wilfrid Laurier University Press, 1991), 86.

${ }^{109}$ CVMRR, Box 3-3, 13 April 1983, Minutes, Adult Education Division Meeting.

${ }^{110} \mathrm{CVMRR}$, Adult Education 330 (Correspondence) by Michael Clague, 1985.

"Personal correspondence, Daniel Pratt, 29 May 2000.

${ }^{112}$ Pratt, "Tutoring Adults: Toward a Definition of Tutorial Role and Function in Adult Basic Education" Adult Literacy and Basic Education 7, 3 (1983): 138-52; Pratt, "Teaching Adults: A Conceptual Framework for the First Session," Lifelong Learning 7, 6 (April 1984): 7-9, 28-9; Pratt, "Andragogical Assumptions: Some Counter-Intuitive Logic," Proceedings of the 25th Adult Education Research Conference (Raleigh: North Carolina State University, 1984), 147-53.
} 
these changes. Phil Candy, for example, wrote a doctoral thesis in the Department with Boshier and Pratt based on "constructivist" psychology. ${ }^{113}$

Tom Sork, arriving in 1981 with a doctorate from Verner's former department at Florida State University, rejected a quantitative approach in his programme planning and evaluation research, ${ }^{114}$ seeking to create a normative model to help planners decide priorities. He considered the theoretical foundations of programme planning models, noting that the body of literature on the "technology" of planning literature was largely devoid of theoretical or philosophical analysis. ${ }^{115}$ In examining the assumptions behind programme planning and needs assessment, Sork slowly broke from a scientific view of curriculum planning that ignored the philosophical assumptions and politics of learning objectives. ${ }^{16} \mathrm{He}$ questioned whether programme planning should strive to emulate ideal models-what he called "deductive" planning — proposing instead to investigate how adult educators actually worked. "I7 (In 1987, with tongue in cheek, he even questioned whether adult education theory did or could ever exist. ${ }^{118}$ )

Sork brought these views to graduate and undergraduate programme planning courses, and to courses he taught outside his immediate programme. ${ }^{19}$ Years later, however, he still introduced undergraduate students to the scientific conception of educational planning. ${ }^{120} \mathrm{He}$ worked with students on a wide range of research interests, some creating and testing programme planning models, others exploring social change and new sociological ideas.

Social change and the sociology of adult education were main interests of Kjell Rubenson, who arrived from Sweden as a tenured professor in 1982 thanks

${ }^{113}$ Phil Candy, “Reframing Research Into 'Self Direction' In Adult Education" (Ed. D. thesis, University of British Columbia, 1987).

${ }^{114}$ CVMRR, Box 2, Adult Education Search Committee 1980-81 folder, n.d. Announcement of appointment.

${ }^{115}$ Sork, "Development and Validation of a Normative Process Model for Determining Priority of Need in Community Adult Education," Proceedings of the 20th Annual Adult Education Research Conference (Ann Arbor: University of Michigan, 1979), 75-81;John H. Buskey and Sork, "From Chaos to Order in Programme Planning: A System for Selecting Models and Ordering Research," Proceedings of the 23rd Annual Adult Eduation Research Conference (Lincoln: University of Nebraska, 1982); Sork and John H. Buskey, "A Descriptive and Evaluative Analysis of Programme Planning Literature, 1950-1983," Adult Education Quarterly 36, 2 (Winter 1986): 86-96.

116Sork, "Needs Assessment in Adult Education: A Critical Analysis of the Literature Through 1981," Proceedings of the 24th Annual Adult Edwation Research Conference (Montréal: Concordia University, 1983), 217-22.

${ }^{117}$ Sork, "The Postmortem Audit: A Research Methodology for Building InductivelyDerived Planning Theory," Proceedings of the 27th Annual Adult Eduation Research Conference (Syracuse: Syracuse University, 1986), 255-60.

${ }^{118}$ Darryl B. Plecas and Sork, "Adult Education: Curing the Ills of an Undisciplined

Discipline," Adult Education Quarterly 37, 1 (Fall 1986): 48-62.

${ }^{119}$ UBC Calendar, 1983-1984 (insert). "Adult Education" was now one of three

"Divisions" in a larger department.

${ }^{120} \mathrm{PC}$, Adult Education 329, 1991, Class notes. 
to Griffith's direct efforts. ${ }^{121}$ Rubenson brought an international reputation to the department as the first professor of adult education at Gothenburg University, and experience as a policy analyst in a country with a long tradition of institutionalized forms of adult education. ${ }^{122}$

Well versed in the North American literature of adult education and social science, Rubenson saw opportunities to broaden research. Like Boshier (whom he cited), Rubenson was interested in adult education participation. He used American cognitive psychology to explain participation, but sought a more complete explanation in social and historical circumstances. He criticized North American research as excessively "applied" and inadequately theoretical, and suggested benefits from adding new sociological perspectives to an overly psychologistic and parochial adult education tradition. Rubenson was particularly interested in government policy support of adult education, an area of research not amenable to the currently popular psychological or theoretical approaches. ${ }^{123}$

Rubenson sought theoretical frameworks in adult education, but had in mind broad theory to inform specifics about adult education. He rejected the "natural science model" as inappropriate for social inquiry, and considered science merely as "a branch of knowledge gained by systematic study," but upheld the quest for unique adult education theory. He cautioned that adult educational researchers "cannot look for theories comparable to those in the natural sciences, but only search for theories which explain situationally-bound regularities determined by the social context." With this distinction in mind, he favoured empirical research (rejecting humanistic psychology for its lack of empirical support) informed by greater historical consideration. He supported mathematical models of social phenomena, but intended them to be flexible. Theory should permeate courses taught in the department, not merely be the object of a special course. ${ }^{124}$

Rubenson taught "Foundations" courses, a new course on international dimensions of adult education, research review courses, and doctoral seminars. In debates on the curriculum revision of the early 1980s, he lamented lack of

${ }^{121}$ CVMRR, Box 2, Adult Education Search Committee 1980-1981 folder, 19 December 1980, Griffith to Rubenson; 11 March 1981, Griffith to Hills; CVMRR, Dr. Griffith's Correspondence Box, General Correspondence (as Professor) Fall 1981 folder, 27 November 1981, Griffith to Bown. Griffith regarded Rubenson as holding a "quasi-Marxist" view.

${ }^{122}$ Paul Bergevin, Adult Education in Sweden (Bloomington: Bureau of Studies in Adult Education, 1961); Rubenson, Recruitment in Adult Education (Stockholm: Department of Educational Research, School of Education, 1976); Personal correspondence, Rubenson, 20 June 2000.

${ }^{123}$ Rubenson, “Adult Education and Allocation Policy in Sweden," Proceedings of the 21st Adult Education Research Conference (Vancouver: University of British Columbia, 1980), 273-81; Rubenson, "Adult Education Research: In Quest of a Map of the Territory, ${ }^{\circ}$ Adult Education 32, 2 (Winter 1982): 57-74; Rubenson, "Background and Theoretical Context," in Cunningham, ed., Yearbook of Adult and Continuing Education (Chicago: Marquis Academic Media, 1980), 217-24.

${ }^{124}$ Rubenson, Recruitment in Adult Education; CVMRR Box 1-3, 12 January 1983, Rubenson to Buttedahl, Boshier, et al. 
electives. ${ }^{125}$ Rubenson was well acquainted with competing social theories, and many of his students examined political topics informed by broader sociological, philosophical, and educational thought. He even sided with students who challenged department admissions standards. ${ }^{126}$

The last new faculty member hired in the early 1980 s was also, significantly, the first woman. Paz Buttedahl, initially a research associate and sessional instructor in 1982, fit the changing times and helped encourage those changes. As a Canadian woman she fit the university's new hiring policies, and she had useful connections with international development agencies. ${ }^{127} \mathrm{~A} \mathrm{PhD}$ from Florida State University, Buttedahl echoed some earlier educational and academic patterns, but fit the new political climate. Her correspondence course "Institutions of Adult Education" cited Verner's colleagues in the company of Marx and, in particular, Paulo Freire (who visited the Department in 1983). She stressed theory, considered definitions and the "discipline" of adult education, and set educational objectives, but she also spoke of "praxis," contrasting social philosophies, and the values that underlay educational practice. ${ }^{128} \mathrm{Her}$ thesis students were compelled to consider "alternative theories and criticism." Buttedahl's appointment was short-term, and she left in 1986 to work as an educational consultant, returning from time to time as a sessional instructor.

In the early 1980s, Griffith told colleagues that adult education research emphasized "theory and method" and "theoretical conceptualization more than empirical research." ${ }^{129} \mathrm{He}$ helped lobby the Social Sciences and Humanities Research Council for increased research funding. SSHRC was particularly interested in funding "theory-oriented" research, interpreted by UBC education researchers as the production of generalizable knowledge. ${ }^{130}$ The call for theory was nothing new in adult education, but theory and research had acquired a broader meaning; Verner's influence was minimal. Concurrent with this shift was

${ }^{125}$ CVMRR, Box 1-3, 12 January 1983, Rubenson to Paz, Roger, et al.

${ }^{126}$ CVMRR, Box 3-4, 14 and 19 March 1984, Minutes.

${ }^{127}$ CVMRR, Box 2, 1978-79 Search Process folder, 29 September 1978, Selman to Griffith; 10 April 1979, Kidd to Search Committee. Faculty of Education Fonds, Deans and Directors Binder, vol. 3, 15 March 1976, Kenny to Deans; CVMRR, Brazil Project Box 1, Correspondence internal folder; 17 December 1985, Collins to Buttedahl, 24 January 1986, Owens to Birch; CIDA-Contract folder, 11 February 1986, Contract; Brazil Project Box 6, 7 August 1984, Buttedahl to Larkin. CVMRR, Box 2, 1978-79 Search Process folder, 22 January 1979, Selman to Search Committee.

${ }^{128}$ CVMRR, Adult Education 328 correspondence course (Institutions of Adult Education) by Buttedahl, 1982.

${ }^{129}$ Faculty of Education Fonds, Faculty Personnel Committee 1984-85-86 Binder, Minutes, 12 November 1985.

${ }^{130} \mathrm{John}$ Andrews and W. Todd Rogers, "Summary and Recommendations" in Canadian Research in Education: A State of the Art Review, 17; Griffith and Pearl J. Roberts, "Adult Education" in Andrews and Rogers, Canadian Research in Education: A State of the Art Review, 38. 
an increase in teaching "Foundations" topics, and in cooperation with Faculty colleagues. ${ }^{131}$

As research and what counted as adult education knowledge broadened, curriculum revisions were to preserve the identity of the adult education programme. Revised diploma and M.Ed. programmes were re-defined as practitioner programmes, and the M.A. and Ed.D. as research programmes. Students could "specialize" in either teaching, administration, or programme planning. All graduate programmes included the "core" courses-Foundations, Programme Planning Theory, and Theory and Research on Adult Learning-as pre-requisites for practical courses, maintaining the old commitment to theory and research as the basis of educational practice. ${ }^{132}$

Under Griffith the new department answered earlier criticisms of intellectual and physical isolation, and the programme became multi-disciplinary, justified by its supposed unique appeal to a clientele of practicing adult educators. ${ }^{133}$ But the place of adult education in the Faculty remained in question. Adult education knowledge based on unique "theory" was never compelling enough to enlist popular support from Faculty colleagues, and in many ways the programme returned to its original purpose: to examine the social, economic, political, and ethical dimensions of adult education practice.

$$
* * *
$$

This overview of adult education studies at UBC from 1957 to 1985 supports two contrasting interpretations. One would be that administrative autonomy protected a valuable intellectual and educational activity from colleagues and practitioners who simply did not understand its value. The second would be that the study of adult education - and the field it purported to study - was not (and could not be) strongly defined nor claimed by any particular group of people using any particular research methodology or educational theory, or in reference to any particular social practice. The resultant tentative and vague boundaries made a weak basis for administrative autonomy in adult education-autonomy that continues to wane at UBC.

${ }^{131}$ Write On: Adult Education Makes the Future (Vancouver: Adult Education Research Centre, 1985), 9.

${ }^{132}$ CVMRR, Box 1-3, 21 October 1983, Sork to AAHE Faculty, Course proposals.

${ }^{133}$ Write On, 53. Student demand continued. 